\title{
Biological and Molecular Characterization of GBNV Infecting Solanaceous Vegetable Crops
}

\author{
H. M. Renuka*, R. Ganesh Naik and M. Krishnareddy \\ Department of Plant Pathology, College of agriculture, University of Agricultural and \\ Horticultural Sciences, Shivamogga, India \\ *Corresponding author
}

\begin{abstract}
A B S T R A C T
Keywords

GBNV, Local lesion, Antisera

Article Info

Accepted:

18 March 2020

Available Online:

10 April 2020

The Groundnut bud necrosis virus (GBNV) induced symptoms such as bud necrosis, chlorotic and necrotic spots on leaves of tomato, chilli and brinjal were collected from field for mechanical inoculation on cow pea (var. C-152) as local lesion host. The electron microscopic observation of the purified preparation of diseased samples showed the presence of spherical, membrane bound particles $(80-120 \mathrm{~nm})$ of typical tospoviruses. Host range study was conducted to GBNV in which Arachis hyopogaea, Vigna unguiculata, Phaseolus vulgaris, Dolichos lablab, Glycine max from Leguminaceae, Cucurbita maxima, Citrullus lanatus from Cucurbitaceae, Gomphrena globasa from Amaranthaceae, four Nicotiana sp. Petunia hybrid, Datura stramonium, D. metal from Solanaceae, Chenopodium quinoa, C. amaranticolor from Chenopodiaceae, Tagetes spp. from Asteraceae, Jasminum sp. from Oleaceae, Vinca rosea from Apocyanaceae, Impatiens sp. from Balsominaceae and some weeds - Solanum nigrum, Physalis minima, Portulaca oleracea, Trianthema portulacastrum showed the local and systemic infection which was similar to GBNV symptoms. For further confirmation DAC-ELISA was performed to all infected plants including tomato, chilli and brinjal samples which showed positive reaction to the GBNV specific antisera. The RT-PCR was performed after total RNA extraction from infected leaves of Solanaceous vegetable crops. A fragment of approximately $0.8 \mathrm{~kb}$ corresponding to the $\mathrm{N}$ gene of $\mathrm{S}$ RNA was amplified, cloned and sequenced. The nucleotide sequence of $\mathrm{N}$ gene from the infected Solanaceous vegetable crops showed highest identities of $93 \%$ to $99 \%$ nucleotide with other GBNV isolates of black gram (AY512650.1), tomato (AY463968.1), pea (JF281101), chilli (AY618567.1), Solanum nigrum (KX244339.1), (KX244334.1), groundnut (JX198661.1) and potato (AF515821.1).
\end{abstract}

\section{Introduction}

Vegetables play an important role in balanced nutrition as they are valuable source of carbohydrates, proteins, vitamins and minerals. Solanaceous vegetables are grown throughout the year in all parts of the country in an area of $3.98 \mathrm{MH}$ with the production of 82.38 Million Tons in 2016-17 (agricoop.nic.in). Currently viral diseases are the major production constraints in Solanaceous vegetable crop production. 
Among the viral diseases, tospoviruses are emerging as a significant limiting factor for the sustainable production of Solanaceous vegetables in India. Depending on the stage of the crop and season GBNV causes yield loss up to $100 \%$. GBNV belongs to the genus Tospovirus and family Bunyaviridae and is economically one of the most important plant virus worldwide (Krishna Reddy et al., 2008; Kunkalikar et al., 2010; Mandal et al., 2012). It is transmitted by thrips (Thrips palmi) in a persistent manner (Lakshmi et al., 1995). GBNV causes chlorosis, necrosis and necrotic ring spots on leaves, fruits and stems of the host plants and infection often leads to necrosis and death of plants (Jain et al., 2004; Raja and Jain, 2006). The virus particle is enveloped, quasi-spherical (80-120 nm diameter) and has a tripartite (L-large, Mmedium and S-small), single-stranded, ambisense RNA genome (Mandal et al., 2012) (Fig. 1).

\section{Materials and Methods}

\section{Source of inoculum}

The GBNV infected leaf samples of tomato, chilli and brinjal were collected from the naturally infected fields of Hesaraghatta (Bangalore rural), Nyamati (Davanagere) and Sunkatannur (Mandya) respectively (Fig. 2).

The virus was initially identified based on direct antigen coated enzyme linked immune sorbent assay (DAC-ELISA) and the virus was maintained on 7-8 days old cowpea (cv. C-152) seedlings through mechanical sap inoculation which were raised from seeds under insect proof glasshouse conditions for purification and to avoid mixed infection by using $0.1 \mathrm{M}$ phosphate buffer. Infected cowpea (cv. C-152) leaves (Fig. 3) were used for further mechanical sap inoculations on different host plants.

\section{Electron microscopy}

The final viral suspension from infected leaf samples of tomato, chilli and brinjal was obtained by partial purification and it was taken for electron microscopic studies. The formavar coated grids were floated on purified viral suspension for 10 minutes. Then, stained the grids with 2 per cent phosphotungstic acid (PTA) for five minutes, the excess stain was drained by touching a blotting paper strip to the edge of the grid. The grids were dried for 15-30 $\mathrm{min}$ in dessicator and examined under transmission electron microscope (Hitachi, Japan) at various magnifications and taken the picture of viral particles.

\section{Host range studies}

For the determination of host range of GBNV, virus was inoculated to 27 plant species belonging to 11 different families i.e. Leguminaceae, Cucurbitaceae, Amaranthaceae, Solanaceae, Chenopodiaceae, Asteraceae, Oleaceae, Apocynaceae, Balsaminaceae, Portulacaceae and Aizoaceae were tested (Table 1). Tomato isolate of GBNV was used for sap inoculation on different host plants. Mechanically inoculated plants were monitored for the expression of symptoms up to 25-30 days post-inoculation (dpi) in an insect proof greenhouse. Local and systemic infections were confirmed by observing symptoms on inoculated and newly emerged leaves and further confirmation through DAC-ELISA by using GBNV specific antisera.

\section{RNA extraction from infected samples}

Total RNA was extracted from young symptomatic leaves of all four vegetable crops using TRI reagent (Sigma, USA) by following the manufacturer's instructions and it was used as a template for the reverse 
transcription-polymerase chain reaction (RTPCR) using GBNV specific reverse primer for cDNA synthesis.

\section{PCR amplification, cloning and sequencing}

Three microliters of RT reaction was used for PCR amplification using Taq DNA polymerase (Thermoscientific). Primer sets of GBNVF ('5-ATCGATCATATGTCTAACG TCAAGCAACTC-3') and GBNVR ('5CTAGGGATCCTTACAATTCCAGCGAAG GACC-3') were used to amplify S RNA of nucleocapsid protein $(\mathrm{N})$ gene. The PCR was performed with initial denaturation at $94{ }^{\circ} \mathrm{C}$ for 3 min followed by 35 cycles of $45 \mathrm{sec}$ of denaturation at $94{ }^{\circ} \mathrm{C}, 1 \mathrm{~min}$ of annealing at $60{ }^{\circ} \mathrm{C}$ and extension for $1.30 \mathrm{~min}$ at $72{ }^{\circ} \mathrm{C}$ followed by a final extension for $20 \mathrm{~min}$ at 72 ${ }^{\circ} \mathrm{C}$. The amplified PCR products were loaded on $1 \%$ agarose gel and DNA eluted using gel extraction kit (GeneElute Gel Extraction Kit, Sigma) following the manufacturer's protocol. The purified PCR products of $\mathrm{N}$ gene were cloned, sequenced and compared with those of other GBNV isolates available at NCBI database using the BLASTN search program (http://www.ncbi.nlm.nih.gov/blast).

\section{Results and Discussion}

\section{Electron microscopic study}

The electron microscopic observation of the purified preparation of infected samples showed the presence of spherical virus (80$120 \mathrm{~nm}$ in diameter) in diseased samples of tomato, chilli, and brinjal which were not found in healthy samples. These particles have morphology similar to those of tospoviruses (Sivaprasad and Gubba, 2006). Each viral particle consists of a granular core of nucleocapsids, bounded by a lipid envelope (5 $\mathrm{nm}$ thick), which was covered with surface projections. Similarly spheroidal particles of
GBNV approximately $50 \mathrm{~m} \mu$ diameter, grouped inside a capsule or envelope to give easily flattened and distorted particles of twice that diameter under electron microscope was observed by Best and Palk (1964), Sivaprasad and Gubba (2006), Krishnareddyet al., (2008) and Yin et al., (2014).

\section{Host range and symptoms}

The virus infected 25 of 27 different hosts tested from 11 families (Table 1). The test plant species such as Arachis hyopogaea, Citrullus lanatus, Cucurbita maxima and Tagetes sp., Impatiens sp., vinca rosea and Gomphrena globosa showed systemic symptoms like mosaic with chlorotic ring spots, yellowing and bud necrosis symptoms after 8-10 days of mechanical sap inoculation. Localized chlorotic lesions followed necrotic lesions were observed on leaves of Vigna unguiculata, Phaseolus vulgaris, Dolichos lablab, Glycine max, Nicotiana sp., Datura stramonium, D. metal, Petunia hybrid, Chenopodium quinoa and C. amaranticolor at five days after inoculation. Jasmine showed chlorotic ring spots on leaves. All the inoculated weed plants are the alternate host to GBNV and the virus produced chlorotic and necrotic ring spots on the Solanum nigrum, Physalis minima, Portulaca oleracea and Trianthema portulacastrum. The earlier reports have indicated that infection of GBNV to a range of hosts which was produced systemic and local lesion on several plant species belonging to Amaranthaceae, Boraginaceae, Chenopodiaceae, Compositae, Cucurbitaceae, Leguminaceae and Solanaceae families. Similarly many authors reported that GBNV infects the members of families Amaranthaceae, Asteraceae, Chenopodiaceae, Cucurbitaceae, Compositae, Fabaceae, Solanaceae and Malvaceae (Raja, 2005; Saritha and Jain, 2007; Mandal et al., 2012., Pavithra et al., 2016). 
Table.1 GBNV infection on different host plants

\begin{tabular}{|c|c|c|c|c|c|c|}
\hline $\begin{array}{l}\text { Sl. } \\
\text { No. }\end{array}$ & Name of the host & $\begin{array}{c}\text { No. of } \\
\text { plants } \\
\text { Inoculated }\end{array}$ & $\begin{array}{c}\text { No. of } \\
\text { plants } \\
\text { infected }\end{array}$ & $\begin{array}{c}\text { Transmission } \\
(\%)\end{array}$ & $\begin{array}{l}\text { Symptoms } \\
\text { Observed * }\end{array}$ & $\begin{array}{c}\text { Confirmation } \\
\text { by DAC- } \\
\text { ELISA }\end{array}$ \\
\hline & Leguminaceae & & & & & \\
\hline 1. & Arachis hyopogaea & 10 & 10 & 100 & CRS, NS & + \\
\hline 2. & Vigna unguiculata & 10 & 10 & 100 & CLL , NLL & + \\
\hline 3. & Phaseolus vulgaris & 10 & 10 & 100 & CRS & + \\
\hline 4. & Dolichos lablab & 10 & 10 & 100 & CRS & + \\
\hline 5. & Glycine $\max$ & 10 & 10 & 100 & CRS & + \\
\hline \multirow[t]{2}{*}{6.} & Vigna mungo & 10 & - & - & - & - \\
\hline & Cucurbitaceae & & & & & \\
\hline 7 & Citrullus lanatus & 10 & 10 & 100 & CL & + \\
\hline \multirow[t]{2}{*}{8} & Cucurbita maxima & 10 & - & 0 & $\mathrm{M}, \mathrm{CRS}$ & + \\
\hline & Ameranthaceae & & & & & \\
\hline \multirow[t]{2}{*}{9} & Gomphrena globosa & 10 & 10 & 100 & NS & + \\
\hline & Solanaceae & & & & & \\
\hline 10 & Nicotiana tabacum & 10 & 10 & 100 & CRS & + \\
\hline 11 & Nicotiana glutinosa & 10 & - & - & - & - \\
\hline 12 & Nicotiana benthamiana & 10 & 10 & 100 & CLL, $\mathrm{N}$ & + \\
\hline 13 & Nicotianarustica & 10 & 10 & 100 & CLL, NLL & + \\
\hline 14 & Nicotiana occidentalis & 10 & 10 & 100 & CLL, NLL & + \\
\hline 15 & Solanum nigrum & 10 & 10 & 100 & CRS, N & + \\
\hline 16 & Petunia hybrid & 2 & 2 & 100 & CLL, NLL & + \\
\hline 17 & Datura stramonium & 10 & 10 & 100 & NS & + \\
\hline 18 & Datura metal & 5 & 5 & 100 & $\mathrm{CS}, \mathrm{NS}$ & + \\
\hline \multirow[t]{2}{*}{19} & Physalis minima & 5 & 5 & 100 & $\mathrm{CS}, \mathrm{NS}$ & + \\
\hline & Chenopodiaceae & & & & & \\
\hline 20 & Chenopodium amaranticolor & 10 & 10 & 100 & CLL and NLL & + \\
\hline \multirow[t]{2}{*}{21} & Chenopodium quinoa & 10 & 10 & 100 & CLL and NLL & + \\
\hline & Asteraceae & & & & & \\
\hline \multirow[t]{2}{*}{22} & Tagetes sp. & 4 & 4 & 100 & $\mathrm{BN}$ & + \\
\hline & Oleaceae & & & & & \\
\hline \multirow[t]{2}{*}{23} & Jasminium sp. & 1 & 1 & 100 & CRS & + \\
\hline & Apocynaceae & & & & & \\
\hline \multirow[t]{2}{*}{24} & Vinca rosea & 4 & 4 & 100 & BN, NLL & + \\
\hline & Balsaminaceae & & & & & \\
\hline \multirow[t]{2}{*}{25} & Impatiens sp. & 6 & 6 & 100 & CLL, NLL, BN & + \\
\hline & Portulacaceae & & & & & \\
\hline \multirow[t]{2}{*}{26} & Portulaca oleracea & 4 & 4 & 100 & CRS & + \\
\hline & Aizoaceae & & & & & \\
\hline 27 & Trianthema portulacastrum & 3 & 3 & 100 & CRS , NRS & + \\
\hline
\end{tabular}

*CRS- Chlorotic ring spots, NRS - Necrotic ring spots, BN - Bud necrosis, CLL - Chlorotic local lesions, NLL - Necrotic local lesions $\mathrm{M}$ - Mosaic, NS - Necrotic spots, CS- Chlorotic spots 
Fig.1 Spherical virus particles as seen under TEM (Magnification of 10, 000X)

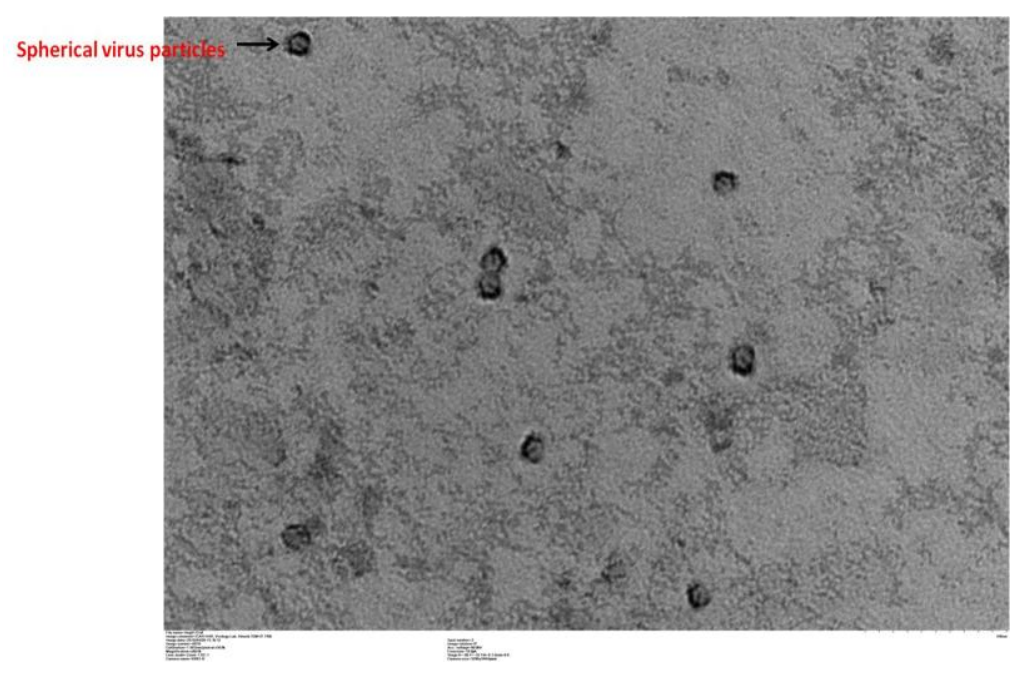

Fig.2 GBNV infected field symptoms on a. tomato, b. chilli and c. brinjal

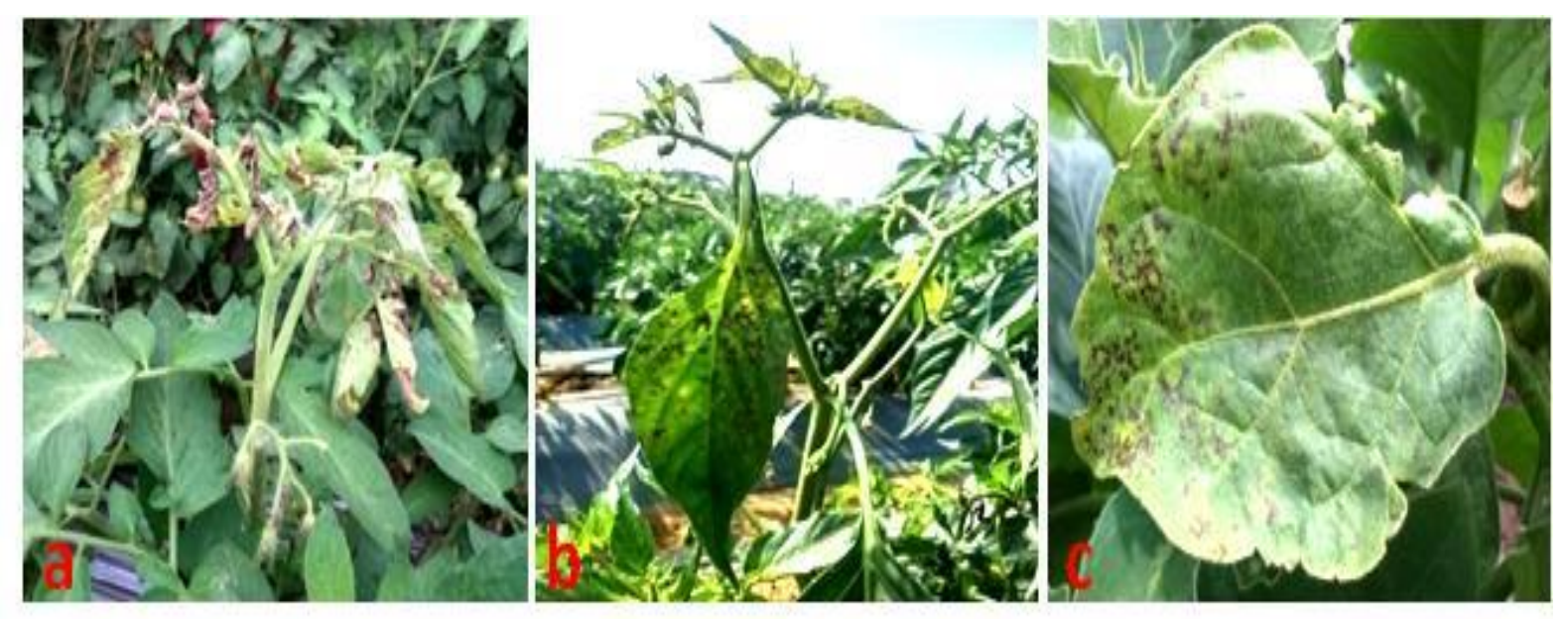

Fig.3 Maintenance of GBNV on cowpea (cv. C- 152) seedlings

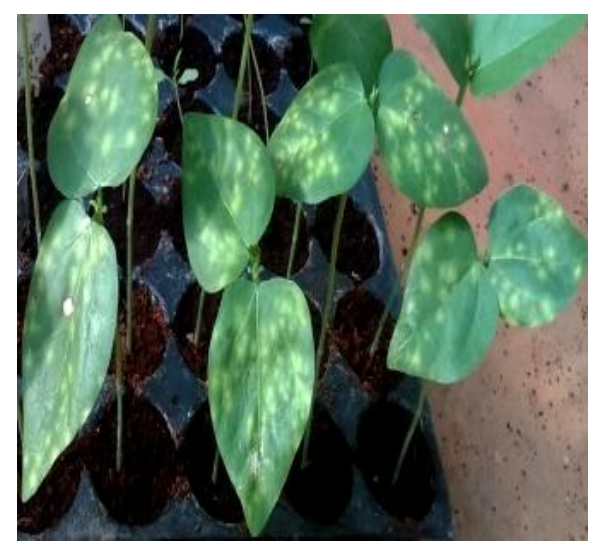


Fig.4 Gel picture showing amplification of $\mathrm{N}$ gene in GBNV infected samples

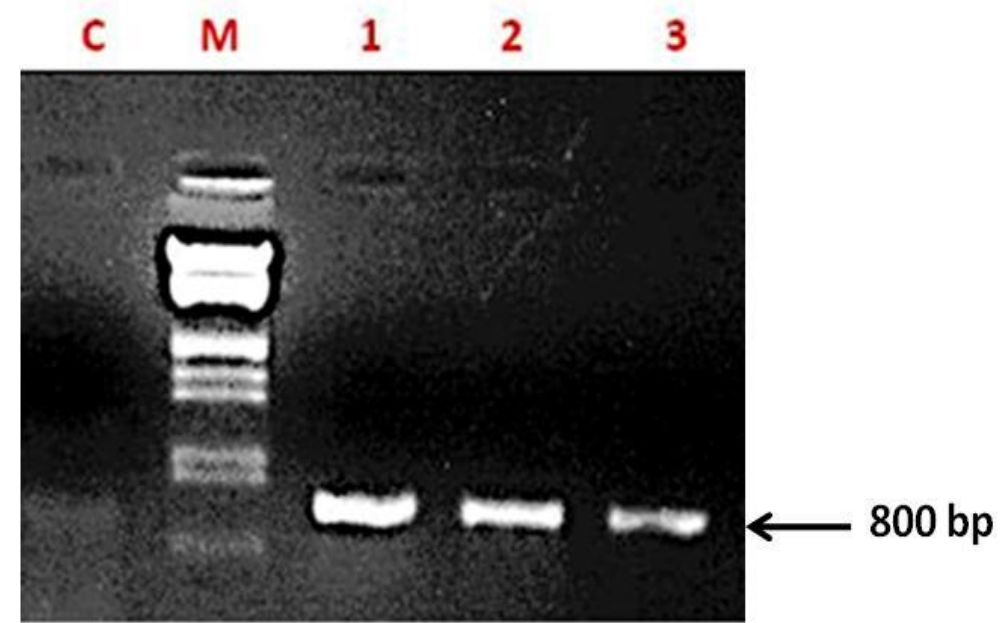

Lane C: Water control, Lane M: Lambda DNA/ECOR1+HindIII Marker, Lane 1-3: Infected tomato, chilli and brinjal respectively

Compositae and Solanaceae have largest range of host plants susceptible to GBNV (Prins et al., 1996).

\section{DAC-ELISA}

This technique was standardized and used for the detection of GBNV in 27 different host plants including tomato, chilli, and brinjal. Mechanically inoculated different hosts were tested by the direct antigen coating enzyme linked immunosorbent assay (DACELISA).The results revealed that the virus showed positive reaction to tospovirus antiserum which was later confirmed as groundnut bud necrosis virus through amplification and sequencing. Similar result was obtained by (Knierim et al., 2006; Chiemsombat et al., 2008; Anurag, 2012) for identification of other tospoviruses like CaCV, TNRV.

\section{$\mathrm{N}$ gene sequencing}

Total RNA was extracted from the infected leaves of tomato, chilli, and brinjal. cDNA synthesis followed by PCR amplification using $\mathrm{N}$ gene specific primers amplified DNA fragment of $0.8 \mathrm{~kb}$ (Fig. 4). The PCR amplified fragments were cloned and sequenced. The analysis of sequence revealed that the $\mathrm{N}$ gene sequence of tomato isolate showed $93 \%$ to $98 \%$ nucleotide identity with black gram (AY512650.1) and tomato (AY463968.1), chilli isolate showed 97\%to $99 \%$ nucleotide identity with pea (JF281101) and chilli (AY618567.1), brinjal isolate showed $97 \%$ to $99 \%$ nucleotide identity with Solanum nigrum (KX244339.1) and groundnut (JX198661.1) of other known GBNV isolates available at NCBI database.

In conclusion the comparative sequence analysis of GBNV of the $\mathrm{N}$ gene of tomato, chilli, and brinjal isolates showed highest identities of $93 \%$ to $99 \%$ nucleotide with GBNV isolates of black gram (AY512650.1), tomato (AY463968.1), pea (JF281101), chilli (AY618567.1), Solanum nigrum (KX244339.1), groundnut (JX198661.1), potato (AF515821.1) and Solanum nigrum (KX244334.1). The GBNV has a very broad host range infecting many economically important crops. Natural infection of GBNV on other crops should also be monitored. It gives information about disease spread and helps in managing the disease. 


\section{References}

Anurag, S., 2012, The occurrence and disease incidence of tospovirus infecting pepper (Capsicum annuum L.) in Southern Thailand. The Philipp. Agrcl. Scientist, 95 (4): 411-415.

Best, R. J. and Palk B. A., 1964, Electron microscopy of strain $E$ of tomato spotted wilt virus and comments on its probable biosynthesis. Virology, 23 (4): 445-460.

Chiemsombat, P., Gajanandana, O., Warin, N., Hongprayoon, R., Bhunchoth, A. and Pongsapich, P., 2008, Biological and molecular characterization of tospoviruses in Thailand. Arch. Virol., 153:571-577.

Jain, R.K., Paul Khurana, S.M., Bhat, A.I. and Chaudhary, V., 2004, Nucleocapsid protein gene sequence studies confirm that potato stem necrosis disease is caused by a strain of groundnut bud necrosis virus. Indian Phytopathol.,57: 169-173.

Knierim, D., Blawid, R. and Maiss, E., 2006, The complete nucleotide sequence of a Capsicum chlorosis virus isolate from Lycopersicum esculentum in Thailand. Arch Virol., 151: 1761-1782.

Krishnareddy, M., Usha Rani, T.R., Kumar, A., Madhavireddy, K. and Pappu, H.R., 2008, First report of Capsicum chlorosis virus (Genus Tospovirus) infecting chilli pepper (Capsicum annuum) in India. Plant Dis., 92:1469.

Kunkalikar, S. R., Sudarsana, P., Rajagopalan, P., Usha B. Zehr and Ravi, K. S., 2010, Biological and molecular characterization of Capsicum chlorosis virus infecting chilli and tomato in India. Arch Virol., 155 (7):1047-57.

Lakshmi, K. V., Wightman, J. A., Reddy, D.V.R., Ranga Rao, G. V., Buiel, A. A. M., Reddy, D. D. R., 1995, Transmission of peanut bud necrosis virus by Thrips palmi in India. pp. 179
184. In Parker, B. L., Skinner, M., and Lewis T., (eds), Thrips Biology and Management. Plenum, New York.

Mandal, B., Jain, R. K., Krishnareddy, M., Kumar, N. K., Ravi, K. S. and Pappu, H. R., 2012, Emerging problems of tospoviruses (Bunyaviridae) and their management in the Indian subcontinent. Pl. Dis., 96 (4): 468-479.

Pavithra, B.S., Krishnareddy, M. and Rangaswamy, K. T., 2016, Detection and partial characterization of groundnut bud necrosis virus in chilli. I.J.S.N., 7 (4):843-847.

Prins, M., Resende, R. DE. O., Anker, C., Van Schepen, A., De Haan, P. and Goldbach, R., 1996, Tomato spotted Wilt Tospovirus (TSWV) by Thrips tabaci lind (Thysanoptera: thripidae) population originating from leek. Plant Pathol., 48: 700-706.

Raja, P., 2005, Development of nucleocapsid mediated resistance in tomato against Groundnut bud necrosis virus. Ph.D. Thesis. Indian Agricultural Research Institute, New Delhi.

Raja, P. and Jain R. K., 2006, Molecular diagnosis of Groundnut bud necrosis virus causing bud blight of tomato. Indian Phytopathol., 59: 359-362.

Saritha, R. K. and Jain, R. K., 2007, Nucleotide sequence of the $\mathrm{S}$ and M RNA segments of a Groundnut bud necrosis virus isolate from Vigna radiata in India. Arch Virol., 152(6): 1195-1200.

Sivaprasad, B.J. and Gubba, A., 2006, Electron Microscopy Studies of a Tomato Spotted Wilt Virus (TSWV) isolate from Kwazulu-Natal. 44th Annual Conference of the Microscopy Society of Southern Africa (MSSA).

Yin, Y., Zheng, K., Dong, J., Fang, Q., Wu, S., Wang, L. and Zhang, Z., 2014, Identification of a new tospovirus causing necrotic ring spot on tomato in China. Virology, 11:213. 
How to cite this article:

Renuka, H. M., R. Ganesh Naik and Krishnareddy, M. 2020. Biological and Molecular Characterization of GBNV Infecting Solanaceous Vegetable Crops. Int.J.Curr.Microbiol.App.Sci. 9(04): 2085-2092. doi: https://doi.org/10.20546/ijcmas.2020.904.250 